盬床 水腎症を合併したクローン病の 2 例

今村健三郎॰ 八州大学医学部第二内科
八尾 恒良 㭭上 忠彦 尾前 照雄
九州大学医学部第一外科
池田 靖洋 古賀 明俊
九州大学医学部第二病理
岩下 明徳

\title{
OBSTRUCTIVE HYDRONEPHROSIS COMPLICATED WITH CROHN'S DISEASE : REPORT OF TWO CASES
}

Kensaburo Imamura, MD, Tsuneyoshi Yao, MD, Tadahiko Fuchigami, MD and Teruo Omae, MD The Second Department of Internal Medicine, Faculty of Medicine, Kyushyu University

Seiyo IKEDA, MD and Akitoshi Koga, MD

The First Department of Surgery, Faculty of Medicine, Kyushyu University

Akinori IWASHITA, MD

The Second Department of Pathology, Faculty of Medicine, Kyushyu University

概要 クローン病における水腎症の合併は，我ふが調べ得た範囲では，本邦にはその報告例を見な い. 著者らは, 水腎症を合併したクローン病の 2 例を経験したので報告する. 症例 1 は21才, 男性 て，昭和45年に左下腹部痛が出現した。昭和48年，某病院にて漬瘍性大晹炎と猃断され治療を受けて いたが，持続する激しい腹痛のため，炤和52年 6 月，当科に入院した，大腸透視では， $\mathrm{S}$ 状結腸に著

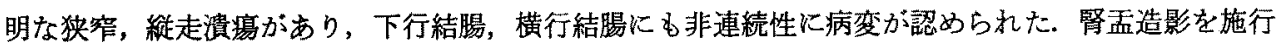
した所, 著しい左側水腎症が認められた 約 2 年半の経過中, 左側水腎症の増悪に加立右側水腎症も 発現した。昭和54年11月，踓患腸管の切除と直腸切断術がなされた. 病理学的に全層性炎症, fissuring ulcer, 肉芽腫が認められ,クローン病と確猃された。術後 3 カ月に行なわれた腎孟造影で, 右側水腎 症の所見は消失し, 左側水腎症も改善していた。症例 2 は23才, 男性で, 昭和 42 年に右下腹部痛が出現 した. 昭和51年, 某病院にてクローン病と診断されたが，昭和52年 8 月，精査执よび治療のため当科 に入院した 小腸透視にて, 回腸末端飞全周性の管腔狭窄と, 中部 下部小腸に䅠走漬瘍が非連続性 汇認められた，留孟造影では右側水腎症が患められた．昭和53年 8 月，罹患腸管の切除が行なわれ， 病理学的検査にてクローン病と確診された。術後 3 カに行なわれた腎孟造影では水腎症の所見はな からた.

\section{緒 言}

最近わが国においても, 確実なクローン病症例

【昭和55年 8 月 19 日受稿】

この論女の一部は，第30回日本消化器病学会九州 地方会（昭和52年12月 $2 ， 3$ 日）に拈いて発表し t.
の報告が年每に増加してきている。クローン病の 合併症として，瘦孔，膿瘍，腸閉塞，肛門部病 変, 関節炎，肝障害などはよく知られているが， 水腎症についての記載は少ない，我々は，水腎症 を合併したクローン病の 2 例を経験したので報告 する。 


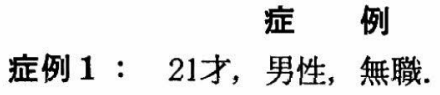

主訴：腹痛, 全身倦总感.

家族歴・既往歴： 特記すべき事項なし。

現病歴：昭和45年, 左下腹部痛が出現した. 昭和47年, 痔核の手術を 2 回にわたつて受けた. 昭和 48 年 8 月, 腹痛が増強したため, 某病院に 入院し，逆行性大腸透視にて潰瘍性大腸焱之診 断された。 その後，ステロイドおよびsalazosulfapyridine (Salazopyrine) 内服にて, 症状は一進一 退を繰り返していた。昭和52年 5 月頃より強い腹 痛が持続するため， 6 月，精査扣よび治療を目的 として当科に入院した.

入院時現症：身長 $179 \mathrm{~cm}$, 体重 $58 \mathrm{~kg}$. 顔貌は 苦悶状. 采養状態不良. 眼䀫結膜は顊血様. 左下 腹部に圧痛と抵抗を認めた。

入院時検查成績（表 1)：中等度の低色素性 貧血, 糞便潜血反応 の強陽性, 中等度 の血沈元 進, CRPの強陽性, $\alpha_{2}$-グロブリンの高值, 低コ レステロール血症, 低カルシウム血症などが陽性 所見であつた，検尿は異常なく，血清尿素窒素, 血清クレアチニン，24時間クレアチニンクリアラ ンスも正常簌囲であつた. PSPは15分值は低值 (8.0\%) を示したが，120分值は 正常範囲（60.2 \%)であつた.

表 1. 入院時検查成績（症例 1)

\begin{tabular}{|c|c|c|c|}
\hline \multicolumn{2}{|l|}{ 検血 } & \multicolumn{2}{|l|}{ 血液生化学 } \\
\hline ヘモグロビン & ン $10.1 \mathrm{~g} / \mathrm{dl}$ & 総蛋白 & $6.5 \mathrm{~g} / \mathrm{dl}$ \\
\hline 赤血球 & $360 \times 10^{4}$ & アルブミン & $47.5 \%$ \\
\hline 白血球 & 8300 & $\alpha_{1}$ ・クロプリン & $8.0 \%$ \\
\hline 検尿 & & $\alpha_{2}$-グロブリン & $11.8 \%$ \\
\hline 蛋白 & $(-)$ & 防クフリン & $12.0 \%$ \\
\hline 榶 & $(-)$ & r゙グロプリン & $20.5 \%$ \\
\hline トンネ & $(-)$ & コレステロール & $85 \mathrm{mg} / \mathrm{dl}$ \\
\hline 中間尿培養 & $(-)$ & カルシウム & $8.5 \mathrm{mg} / \mathrm{dl}$ \\
\hline \multicolumn{2}{|l|}{ 検便 } & 尿素窒素 & $8 \mathrm{mg} / \mathrm{dl}$ \\
\hline 潜血 & $(2+)$ & クレアチニン & $0.6 \mathrm{mg} / \mathrm{dl}$ \\
\hline 虫卵 & $(-)$ & PSP 15 分 & $8.0 \%$ \\
\hline \multirow[t]{2}{*}{ 血沈 } & $18 \mathrm{~mm} 1$ 時間値 & 120 分 & $60.2 \%$ \\
\hline & $\begin{array}{c}4 \mathrm{~mm} 2 \text { 時間値 } \\
(7+)\end{array}$ & クレアチニンクリ & $\begin{array}{l}\text { アランス } \\
148.8 \ell / d\end{array}$ \\
\hline
\end{tabular}

逆行性大腸透視は，激しい腹痛のため，当科入 院直後は施行できなかつたが，入院前に他院にて 行なわれた検査では， $\mathrm{S}$ 状結腸に管腔狭窄，偏側 性管腔狭小，強い粘膜集中を伴つた綎走する傾向 の不整形潰瘍，多数の炎症性ポリープが認められ た. 管腔外矢印部への淡いバリウムの漏出があ り，瘦孔の存在が示唆された（図 1 )。な拉，下 行結腸, 横行結腸にも非連続性に病変が認めら れ、クローン病が強く寲われた. 腹痛とともに持 続性の左側腰部痛を訴えるため, 炎症の後腹膜へ の波及を疑い腎孟造影を行なつた。腎孟造影では, 右側尿路系には巽常はなかつたが, 左側の腎孟, 腎杯，尿管には著明な拡張が認められた（図 2).

入院後経過：入院直後より経口摄取を禁止し て中心静脈栄養を行なつたが，疼痛が持続するた め, 昭和52年 7 月, 手術が行なわれた。 $\mathrm{S}$ 状結腸 は癒着が強く，これを中心として炎症性腫瘤を形 成しており，左尿管はこの部で圧迫されていた。 罹患腸管と腫瘤の摘出は困難と判断され, 回腸約 $40 \mathrm{~cm}$ の切除と姑息的な回腸直腸吻合術が行なわれ た。 その後も腹痛は持続し, 発熱や肛門部の疼痛

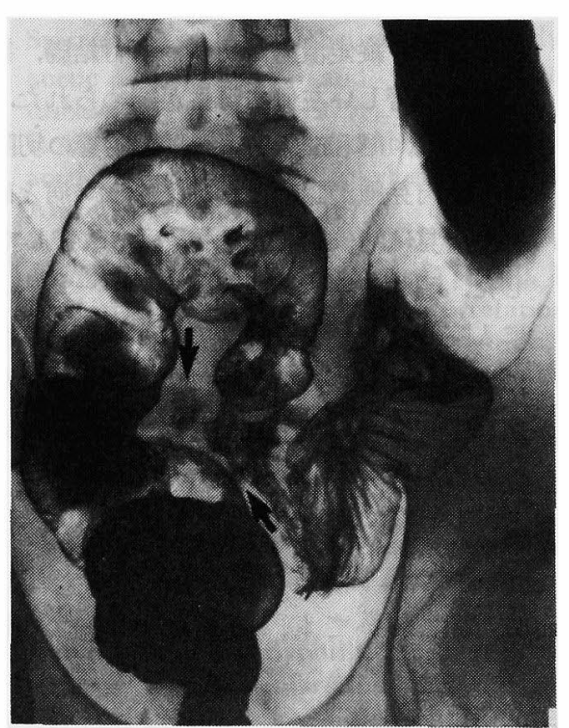

図 1。症例 1。逆行性大腸透視。 $\mathrm{S}$ 状結腸に狭窄, 縦走潰瘍，炎症性ポリープが認められる，管腔外矢 印部にパリウムの漏出がある。 


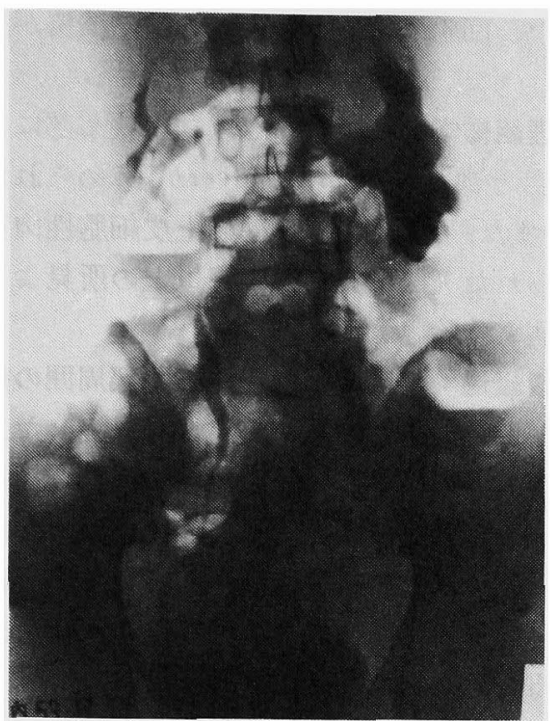

図2, 症例 1。腎孟造影。著明な左側水腎症が認め られる。

も出現し, 肛門部より多量の排膿が認められる様 になつた. 内科的治療に汇とんど反応しないため， 昭和53年 3 月， 2 回目の手術が行なわれたが，S 状結腸部の瘉着が強く, 病変部の摘除は行なわれ なかつた．回腸瘦が造設されたが，同様の症状は 持続した. 昭和54年 9 月に行なわれた逆行性大腸 透視では， $\mathrm{S}$ 状結腸部の狭窄の範囲が広がり, 直 腸部にも辺縁不整を伴う伸展不良が認められる様 になつた. 瘦孔もより顕変になり, $\mathrm{S}$ 状結腸と直 腸間の矢印部に内瘦が認められた（図 3 ). さら に, 腸管と尿管の関係を知る目的で, 逆行性大腸 透視と腎孟造影を併用して行なつた，左側水腎 症の増覀に加えて新たに, 右側水腎症が発現して おり，右側尿管は上直腸部で圧迫されていた（図 4).内科的にはュントロールできないため, 昭 和54年11月, 3 回目の手術が行なわれた.

手術所見：前回造設された回腸㾇を温存し， これより肛側の回腸, 盲腸, 全結腸の切除之, 肛 門部瘦孔を含めての直腸切断術がなされた．その 結果, 尿管の狭窄部は, $\mathrm{S}$ 状結腸, 直腸の病変部 に一致しており, 板状に硬化した後腹膜にとりか こまれ，その走行を全く触知できなかつた。しか

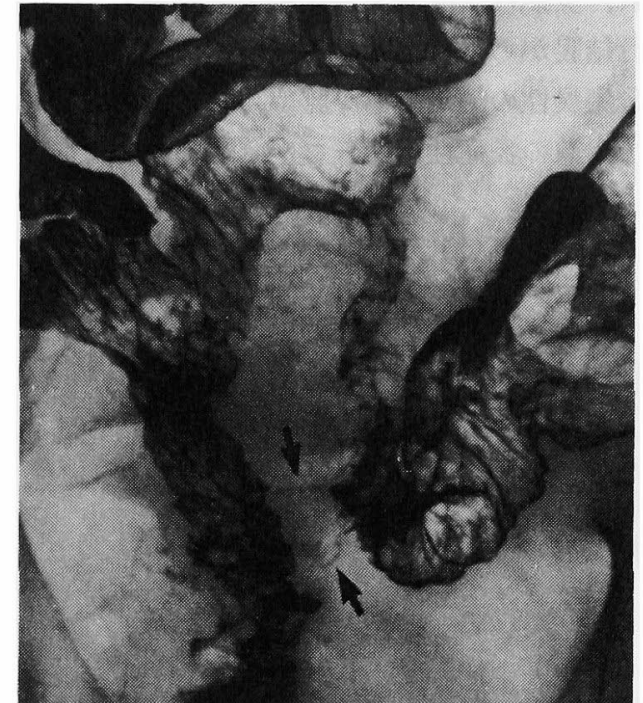

図 3 . 症例 1 、入院後 2 年 3 力月の逆行性大腸透 視. $\mathrm{S}$ 状結腸の狭囬は影著になり, 直腸にも辺縁不 整像, 伸展不良が認められる。矢印部には, 内瘦が 描出されている。

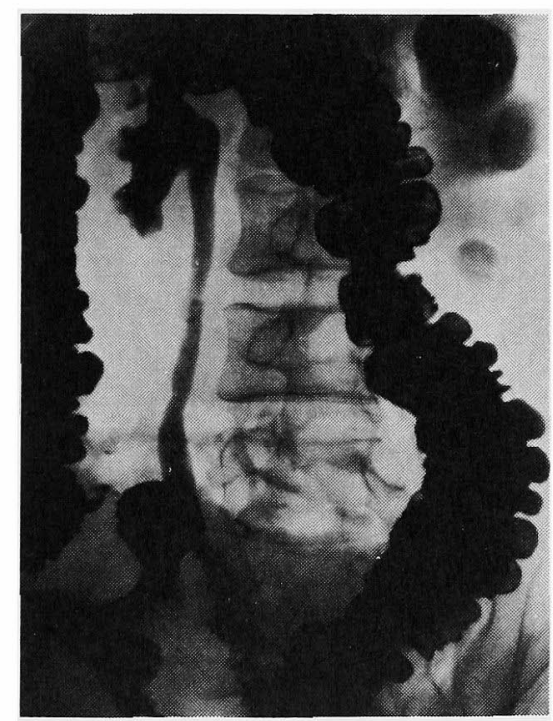

図 4。症例 1 . 入院後 2 年 3 力月の堅孟造影。右側 水腎症が新たに発現している.

し，狭窄は可逆性とみなされ，ureterorlysis を行 ならことなく放置された。

切除標本肉眼所見： $\mathrm{S}$ 状結腸および直腸は癒 着により一塊となり，その壁は著明に肥厚してい た.切開すると， S 状結腸部には著明な狭窄が認め 
られ，炎症性ポリープが密集して存在していた。 横行結腸から下行結腸にかけては,一部開放性, 大 部分症痕性の縦走潰瘍が認められ，この潰瘍に沿 つて少数の炎症性ポリープが認められた（図 5 ).

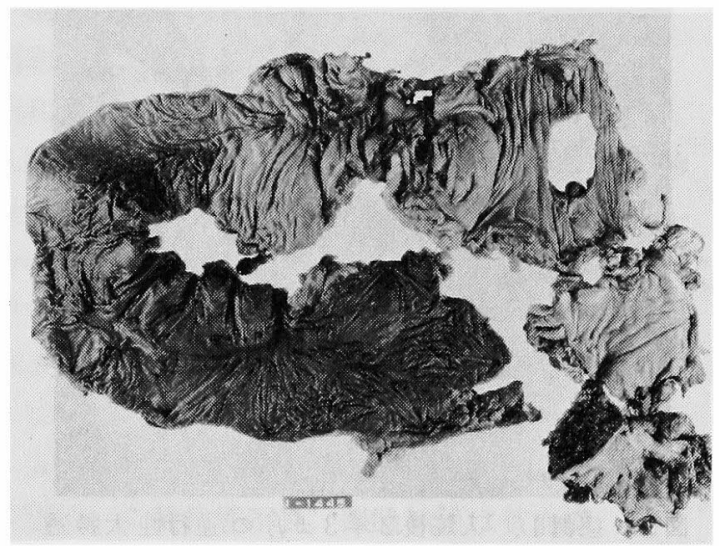

図 5。症例 1。切除標本肉眼像。 $\mathrm{S}$ 状結腸に著明な 狭窄と密集した炎症性ポリープ，その口側に縦走潰 瘍が認められる。

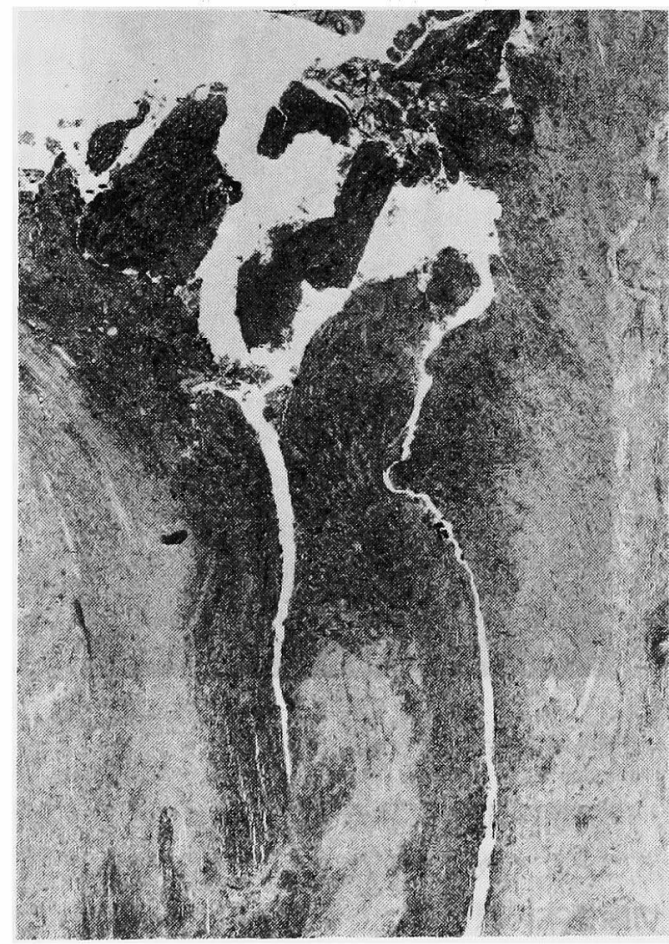

図 6. 症例 1。切除標本組織像 $(H \& \mathrm{E} \times 16)$ 全層 性炎症, fissuring ulcerが認められる.
また，回腸にも浅い疰痕状の樅走潰痬が認めら れた。

病理組織学的所見： $\mathrm{S}$ 状結腸狭窄部には全層 性炎症と典型的fissuring ulcerが認められた（図 6 )。また，粘膜下層内に類上皮細胞性肉芽董加: 認められた（図 7 ).な拈，以上の所見よりクロ ーン病と確診された。

術後経過：術後, 腹痛, 肛門部周囲の疼痛, 発熱などは消失し，昭和55年 3 月退院した。昭和 55 年 2 月, 術後 3 力月目に行なわれた腎孟造影で は，右側水腎症の所見は消失していた，左側の腎 孟，腎杯，尿管の拡張は残存していたが，腎杯の 鈍化, 拡張の所見は軽減し, 左側水腎症も改善し ていると考党られた（図 8).

症例 2 : 23才, 男性, 無職.

主訴：腹痛.

家族歴・既往歴： 特記すべき事項なし.

現病歴：昭和 42 年, 右下腹部痛が出現し, 虫 垂切除を受けた。昭和44年より同部に再び痛みを 覚党る様になつた。昭和50年より痛みの範囲が広 くなり, 頻度も増加した. 昭和51年, 東京都内某 病院に入院し, クローン病と診断され, 高カロリ 一輸液, salazosulfapyridine 投与などの治療を受 けた. なお，この時に施行された上行結腸の生検 にて類サルコイド肉芽腫が検出されている．昭和 52 年 8 月，転居に伴い，精査および加療のため当

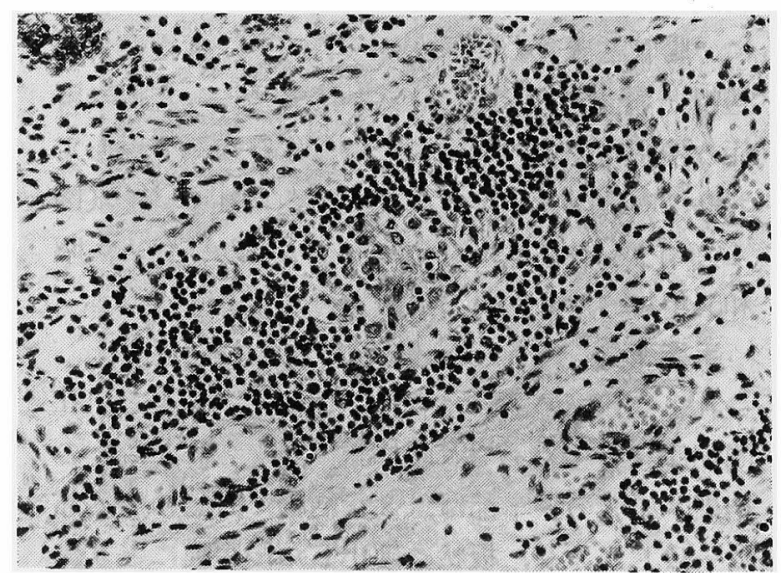

困 7. 症例 1。肉芽腫を示す $(H \& \mathrm{E} \times 310)$ 


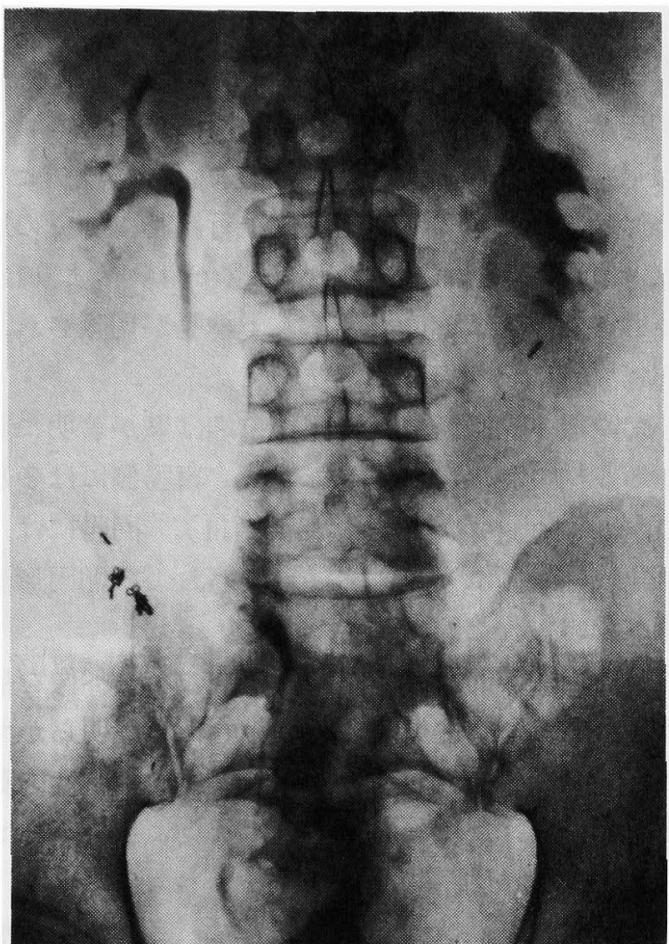

図 8. 症例 1. 術後 3 力月の腎昷造影. 右側水腎症 の消失, 左側水腎症の改善が認められる。

科に入院した。

入院時現症：身長 $166 \mathrm{~cm}$, 体重 $48.5 \mathrm{~kg}$. 栄養 状態不良. 眼検結膜は貧血様. 右季肋部より右下 腹部にかけて圧痛を認め，右下腹部に硬い腫瘤を 触れた。

入院時検查成績（表 2）：中等度の正色素性 貧血, 糞便潜血反応の間歇的陽性, 中等度の血沈 亢進, CRPの強陽性， $\alpha_{2}-$ グロブリンの高值，低 カルシゥム血症などが陽性所見であつた．腎機能 は検尿にて異常を認めず，血清尿素窒素，血清 クレアチニン，24時間クレアチニンクリアランス も正常範囲であつた．PSPは15分値は低値（18.2 \%)を示したが，120分值は正常（87.6\%）であ つた.

小腸 $\mathrm{X}$ 線検査では，回腸末端に，一部に偽䄸室 形成を伴う全周性の管腔狭窄が腫瘤触知部に一致 して認められた（図 9).中部〜下部小腸には， 偏側性の管腔変形, 縰走潰痬が非連続性に認めら
表 2. 入院時検査成績（症例 2)

\begin{tabular}{|c|c|c|c|}
\hline \multicolumn{2}{|l|}{ 検血 } & \multicolumn{2}{|l|}{ 血液生化学 } \\
\hline \multicolumn{2}{|l|}{ へモ } & 総坐白 & $7.2 \mathrm{~g} / \mathrm{dl}$ \\
\hline 赤血球 & $371 \times 10^{4}$ & アルブミン & $55.1 \%$ \\
\hline 白血球 & 9,800 & $\alpha_{1}$-グロプリン & $5.1 \%$ \\
\hline \multicolumn{2}{|l|}{ 検尿 } & \multicolumn{2}{|c|}{$\alpha_{2}$-グロプリン $12.3 \%$} \\
\hline 蛋白 & $(-)$ & ßーグロブリン & $7.6 \%$ \\
\hline 裙 & $(-)$ & \multicolumn{2}{|c|}{$\gamma$ •グロブリン $19.6 \%$} \\
\hline ドンネ & $(-)$ & コレステロール & $185 \mathrm{mg} / \mathrm{dl}$ \\
\hline 中間尿培養 & $(-)$ & カルシウム & $8.4 \mathrm{mg} / \mathrm{dl}$ \\
\hline \multicolumn{2}{|l|}{ 検便 ～～～～～～～～～} & \multicolumn{2}{|l|}{ 尿素窒素 } \\
\hline 潜血 & $(-) \sim(+)$ & クレアチニン & $0.9 \mathrm{mg} / \mathrm{dl}$ \\
\hline 虫卵 & $(-)$ & PSP 15 分 & $18.2 \%$ \\
\hline 血沈 & $3 \mathrm{~mm} 1$ 時間値 & 120 分 & $87.6 \%$ \\
\hline CRP & $\begin{array}{c}38 \mathrm{~mm} 2 \text { 時間値 } \\
(7+)\end{array}$ & \multicolumn{2}{|c|}{ クレアチニンクリフランス } \\
\hline
\end{tabular}

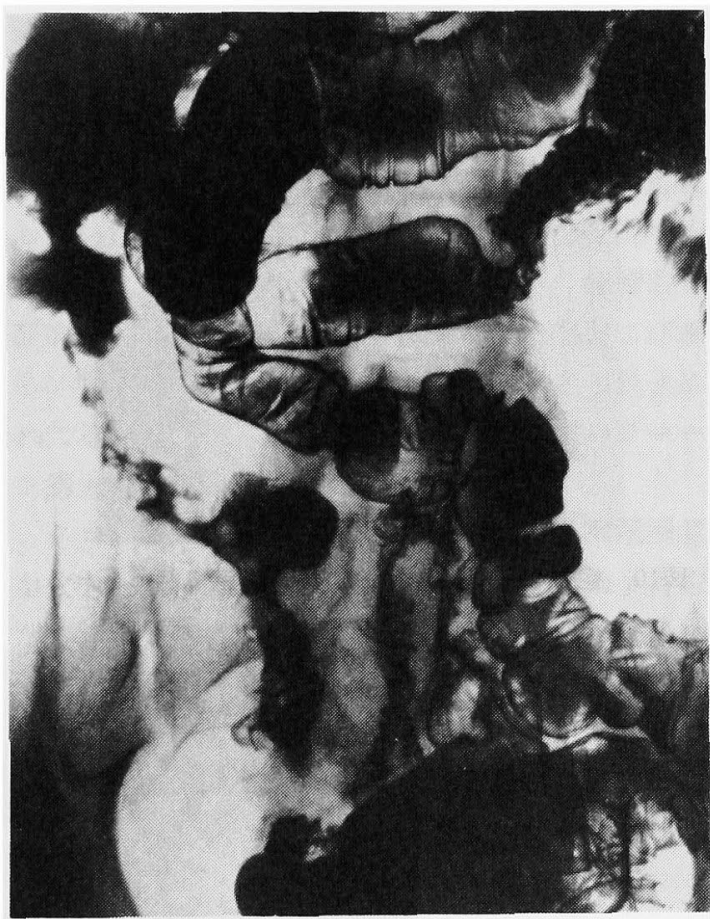

図 9，症例 2。小腸透視。回腸末端に偽秝室形成を 伴5全周性の管腔狭窄が認められる。

れた。逆行性大腸透視では，上行結腸起始部は腫 瘤のため閉塞していた．X線所見や他院にて行な われた生検で肉芽腫が認められた事より，クロー ン病が強く疑われた。腫瘤の存在からクローン病 
の後腹膜への波及を疑い腎孟造影を施行したとこ ろ，右側の腎需，腎杯，尿管の拡張が認められた （図10）．左側尿路系は正常であつた。

入院後経過： Metronidazole (Flagyl) 投与な どにより, 腹部症状, 血沈, CRPの改善を認め, 昭 和52年11月退院した。しかし，昭和53年 2 月頃よ り腹部症状が再然したので，4月に再入院した. 小腸 $\mathrm{X}$ 線検査にて回腸末端部の狭窄が増強してお りまた，腹痛も次第に強くなつたため，8月に 手術が行なわれた。

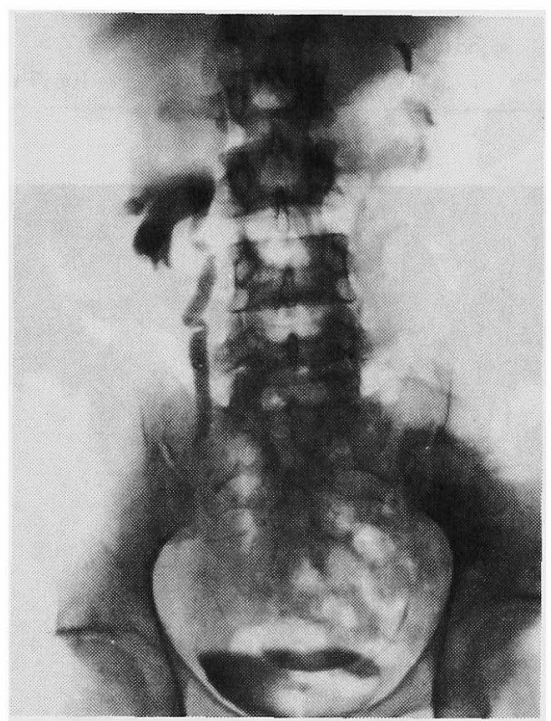

図10, 症例 2. 腎孟造影. 右側水腎症が認められる.
手術所見：術中内視鏡により，小腸には， Treitz勒帯より $160 \mathrm{~cm}$ の部より病変が存在する事 が確かめられた，回腸末端部は，回腸同志および 回腸と盲腸とが癐着し，さらにこれらは一塊とな つて後腹膜に癒着していた。.上行結腸には壁の肥 厚と浆膜の発赤が認められた. Treitz勒帯より120 cmの部より肛門側の小腸と右半結腸が切除され， 空腸横行結腸吻合術が行なわれた。

切除標本肉眼所見：回腸末端は壁が著明に肥 厚し，粘膜面は粗造化していた．盲腸側には多数 のpseudopolypが認められた（図11）。回腸には， 腸間膜付着側に一致して縦走潰瘍拉よび卵円形潰 瘍が認められた。

病理組織学的所見：回腸末端のルーペ像を呈 示したが，全層性炎症と fissuring ulcerが明らかで ある（図12）. また，粘膜内に類上皮細胞性肉芽 腫が認められた。なお，以上の所見よりクローン 病と確診された。

術後経過：術後, 腹痛は消失 し体重も增加 し，昭和53年10月退院した。術後 3 力目目に行な われた腎孟造影では，右側水腎症の所見は消失し ていた（図13）.

\section{考案}

クローン病に打ける水婜症の合併は，1943年の Hyamsら $^{1)}$ の 1 例報告に始まり，近年欧米では， その報告例も增加してきている。 しかし本邦で

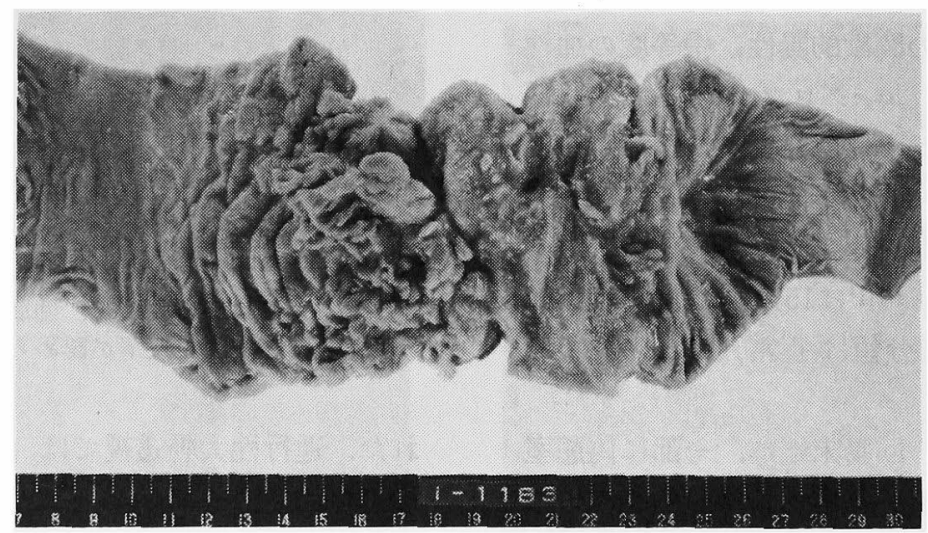

図11. 症例 2 . 切除標本肉眼像. 回盲部の壁の肥厚, 多数のpseudopolyp が認められる。 


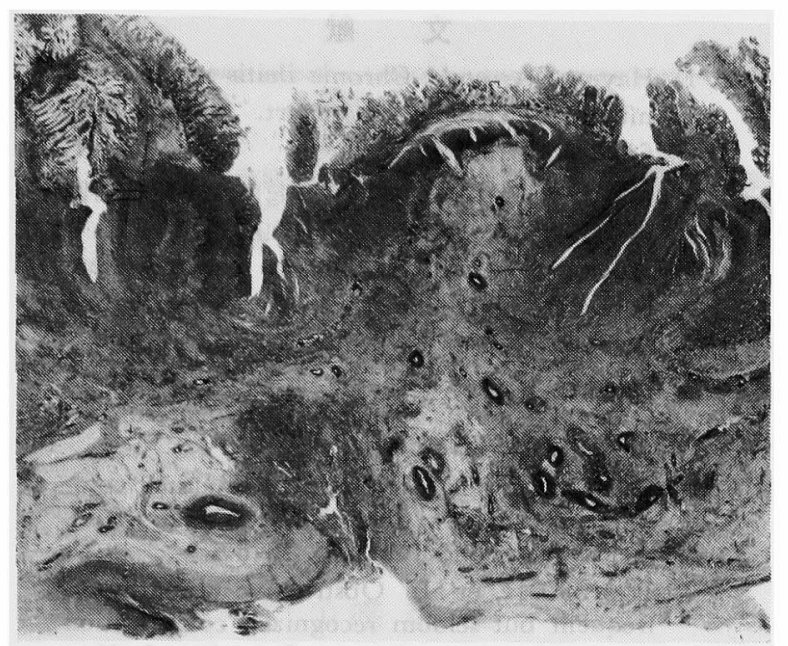

図12. 症例 2。ルーペ像. 全層性炎症, fissuring ulcerが認められる.

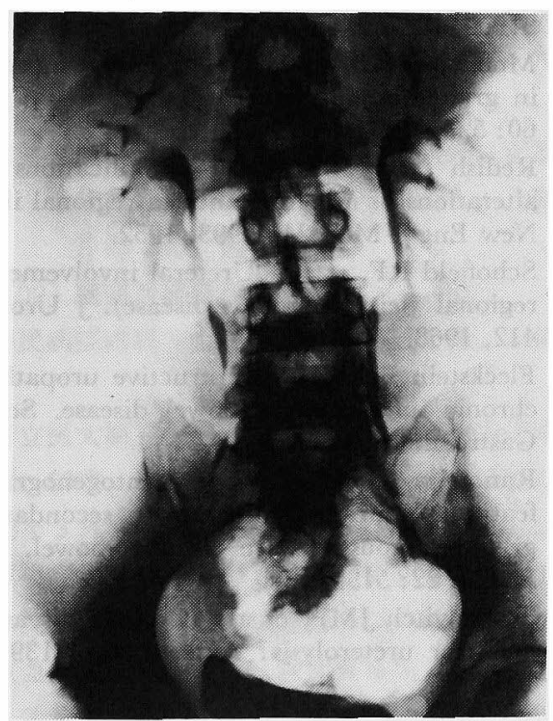

図13. 症例 2 . 術後 3 力月の腎孟造影. 右側水腎症 は消失している。

は，その報告例も殆どなく，余り留意されていな い.すなわち，我々が調べ得た限りでは，緒方 ら ${ }^{2)}$ のクローン病に起因乙水腎症を合併した膀脱 周囲炎の 1 例報告がみられるのみである. しかし この症例の腸管病変についての記載は, 注腸透視 における回盲部の癒着所見と, 術中の浆膜側から の観察所見のみで，しかも腸病変部の切除がなさ
れておらず，クローン病としての診断根拠が充分 でない，我々の 2 例に打いては, 臨床経過, X線 所見, 切除材料の病理学的所見より, クローン病 の診断に問題はない.

通常クローン病に扣ける水腎症の合併は, 腸管 の炎症がfissuring ulcer, 内瘦などを介し後腹膜に 及び，この部で尿管を压迫するために扣こると解 釈されている ${ }^{3) \sim 5)}$. 従つて, クローン病の好発部 位であり, しかも解剖学的に右後腹膜に近接して いる回腸未端の病変に起因する，右側水腎症の合 併が汇とんどである ${ }^{3) \sim 13)}$ ．左側水腎症および両 側水腎症の合併 はまれで ${ }^{93)}$, 左側水腎症は $\mathrm{S}$ 状結腸の病変に基づくとされている，我々の症例 1 は両側水腎症, 症例 2 は右側水腎症の合併例で ある. 水腎症の合併頻度は，5２5\%とまちまち であるが(34)67713)；これらの頻度は扱つた対象， たとえばその重症度によつて異なつていると考兄 られる。すなわち，腫瘤を触れたり，内瘻を形成 している重症のクローン病では水腎症を合併する 頻度は高い, 我々の 2 症例においても, 腫瘤およ び抵抗を触知したこと，強い狭窄，内㿔掞よび激 しい腹痛を有したこと, 病歷が 7 年以上の長きに わたる事などの点で共通しており，重症のクロー ン病と考えられた。

クローン病に合併する水腎症では，通常尿所見 を欠き，血清尿素窒素やクレアチニン值の上昇る なく，特異的な自覚症状も認められない事が多い 3) 4)6) 13)，我々の 2 症例に打いて子，尿路死腔の存 在のために生じたと推测されるPSPの排泄遅延以 外には，腎尿路系の異常を示唆する所見は認めら れなかつた，また，中間尿培養も陰性であつた。 な和，症例 1 は持続性の左側腹部痛を訴えていた が，これが特異的所見とは考えにくい。

クローン病に合併した水腎症の治療に䋆いて， Enkerら ${ }^{71}$ は罹患腸管の切除のみでなく， ureterolysisを加えるべきであると力説しているが, Siminovitchら ${ }^{13)}$ は，水腎症を合併したクローン病の45 例を報告し，ureterolysisは必要ないと述べてい る.我々の症例においても，腫瘤を含めた罹患腸 
管の切除のみで，水腎症は治癔あるいは改善し た。症例 1 に抋いては，病変部の瘉着か強いた め，水腎症が発見されて約 2 年半後に根治的手術 がなされた、この間，当初より認められていた左 側水腎症の堌強に加え，新たに右側水腎症が発現 した.この事は， S 状結腸の病変に起因して左側 後腹膜へ波及した资症が右側後腹膜へも進展した ためと考光られた，幸に，右側水腎症は術後早急 に消失したが，左側尿路系には，術後 3 カ月の時 点では，まだ扗張所見が認められていた。、いずれ にせよ，水腎症の合併はとりもな拈さず，クロ一 ン病の炎症が後腹膜にゅで及んでいる事を示して おり，外科的治療の適応之考えらる(3)1)13).

すでに述べた通り，クローン病に水腎症を合併 しても特異的症状や所見は認められないので，特 に腫瘤を触知する様な患者には，積極的に腎孟造 影を行なう必要があると考光られる。

\section{結 語}

1）水腎症を合併したクローン病の 2 例を報告 した.

2）腫瘤を触知する症例，後腹膜への炎症の波 及が莀われるクローン病症例では皘極的に腎孟造 影を行ならべきである。

3）水腎症を合併したクローン病は，外科的治 療の適応であると思われる。

辢辟症例 1 の手術に際して御協力いたざいた九州 大学泌尿器科熊沢净一助教授および本論文作成に御 協力いたぶいた九州大学放射線科下田悠一郎先生に梁 謝いたします。

\section{文献}

1) Hayms JA, etal : Chronic ileitis with' conco mitant ureteritis. Case report. Amer J Surg $61: 117,1943$.

2) 緒方二郎, 他 : クローン病に起因する膀胱周国 炎の 1 例。西日本泌尿 $36: 599,1974$.

3) Block GE, et al: Significance and treatment of occult obstructive uropathy complicating Crohn's disease. Ann Surg 178: 322, 1973.

4) Steigmann F: Urinary tract complications in regional enteritis. Amer J Gastroenterol 59: $389,1973$.

5) Fasth $S$, et al: Ureteric obstruction complicating Crohn's disease in terminal ileum. Acta Chir Scand 142: 275, 1976.

6) Present $\mathrm{DH}$, et al: Obstructive uropathy-a frequent but seldom recognized complication of granulomatous disease of the bowel. New Engl J Med 280: 528, 1969.

7) Enker WE, et al: Occult obstructive uropathy complicating Crohn's disease. Arch Surg 101: $319,1970$.

8) Mooney RAH, et al: Obstructive uropathy in granulomatous bowel disease. Brit J Surg $60: 525,1973$.

9) Redish MH: Ureteral complications and alterations of ureteral tonus in regional ileitis. New Eng J Med 246: 993, 1952.

10) Schofield RF, et al: Ureteral involvement in regional ileitis (Crohn's disease). J Urol 99: 412, 1968.

11) Fleckstein P, et al: Obstructive uropathy in chronic inflammatory bowel disease. Scan J Gastroenterol 12: 519, 1977.

12) Ranowitz JG, et al: The roentogenographic features of ureteral obstruction secondary to granulomatous disease of the bowel. Clin Radiol 22: 519, 1977.

13) Siminovitch JMP, et al: Crohn's disease-a need for ureterolysis?.Amer J Surg 139: 95, 1980. 